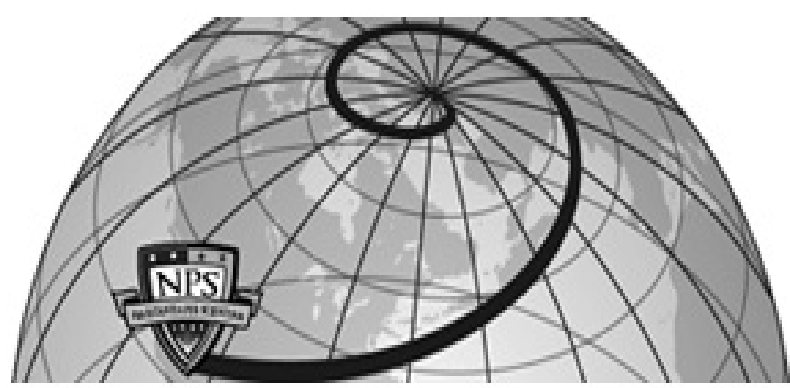

Calhoun: The NPS Institutional Archive DSpace Repository

MATE Center: A Strategy for Improving Marine Technical Education

Sullivan, Deidre; Zande, Jill; Murphree, Tom; Ford, Bruce

https://hdl.handle.net/10945/43398

This publication is a work of the U.S. Government as defined in Title 17, United States Code, Section 101. Copyright protection is not available for this work in the United States.

Downloaded from NPS Archive: Calhoun

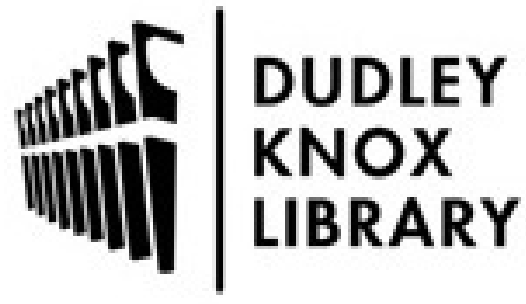

http://www.nps.edu/library
Calhoun is the Naval Postgraduate School's public access digital repository for research materials and institutional publications created by the NPS community. Calhoun is named for Professor of Mathematics Guy K. Calhoun, NPS's first appointed -- and published -- scholarly author.

Dudley Knox Library / Naval Postgraduate School 411 Dyer Road / 1 University Circle Monterey, California USA 93943 


\title{
OTC 16996
}

\author{
MATE Center: A Strategy for Improving Marine Technical Education \\ Deidre Sullivan $^{1}$, Jill Zande ${ }^{1}$, Tom Murphree ${ }^{2}$, Bruce Ford ${ }^{3}$ \\ 1 Marine Advanced Technology Education Center, \\ 2 Naval Postgraduate School \\ 3 Clear Science Inc.
}

Copyright 2004, Offshore Technology Conference

This paper was prepared for presentation at the Offshore Technology Conference held in Houston, Texas, U.S.A., 3-6 May 2004.

This paper was selected for presentation by an OTC Program Committee following review of information contained in an abstract submitted by the author(s). Contents of the paper, as presented, have not been reviewed by the Offshore Technology Conference and are subject to correction by the author(s). The material, as presented, does not necessarily reflect any position of the Offshore Technology Conference or its officers. Electronic reproduction, distribution, or storage of any part of this paper for commercial purposes without the written consent of the Offshore Technology Conference is prohibited. Permission to reproduce in prin is restricted to an abstract of not more than 300 words; illustrations may not be copied. The abstract must contain conspicuous acknowledgment of where and by whom the paper was presented.

\section{Abstract}

A major goal of the Marine Advanced Technology Education (MATE) Center is the creation of appropriate guidelines, assessments, curricula, and programs to provide students and workers with the knowledge and skills they need to excel in marine technology careers.

\section{About the MATE Center}

The Marine Advanced Technology Education (MATE) Center, headquartered at Monterey Peninsula College in Monterey, California, is funded by the National Science Foundation's (NSF) Advanced Technological Education (ATE) and has been in existence since 1997. The MATE Center is a national network of community colleges, high schools, universities, research institutions, marine industries, professional societies, and working professionals. The mission of the MATE Center is to improve marine technical education and in this way help to prepare the nation's future workforce for ocean-related occupations.

\section{Introduction}

The process of developing a competent marine workforce that is well prepared for employment requires collaborating with a wide range of people and organizations. One of the major tasks of the MATE Center is to identify and define marine technical occupations, and the abilities that men and women need in order to perform well in these occupations. The major product that results from this work is a set of occupational knowledge and skill guidelines (KSGs) for technical marine occupations. These guidelines describe what workers need to know and be able to do in order to perform their jobs well. The KSGs are different for each occupation. The KSGs developed by the MATE Center include those for marine technicians, remotely operated vehicle (ROV) technicians, hydrographic survey technicians, aquarists, and aquaculture technicians. The KSGs in their entirety can be found at: http://www.marinetech.org/marineworkforce

The KSGs have been used to identify requirements, or competencies, that are common to two or more occupations. These competencies have then been grouped into educational subject areas in order to facilitate the efficient development of educational materials and programs that are based on occupational requirements. The competency areas developed so far include: safety and seamanship, computer systems, data processing, technical writing, oceanography, meteorology, marine biology, navigation, hydraulic equipment, electronics, surveying, submersibles, math and statistics, interpersonal relations, water quality, small boat operations, physics, instrumentation, machining and fabrication, fluid dynamics, propulsion systems, and geographic information systems (GIS).

The competencies are a critical link between the workplace and the classroom, since they connect job requirements to educational subject areas. The competencies are the basis for the development of instructional materials, starting with assessments based on the competencies, and instructional modules based on the assessments. Assessments and modules are under development for a number of the competency areas listed above. The instructional materials are the foundation for MATE Center courses, student internships, and faculty development workshops, described in the MATE Center papers that follow in this publication.

A key element of all of these products is that they are based on KSGs that have been identified and validated by practicing marine technicians through workshops and surveys conducted by MATE Center staff. Educators then implement the KSGs, by way of the competencies, as they develop the MATE Center's instructional materials, courses, and educational and career management programs. The overall process is shown in the accompanying flow chart (Figure 1).

One of the MATE Center's main goals is to create and improve marine technology education programs at a number of colleges across the country. The workforce studies conducted by the MATE Center help provide a context to align the different programs along a common set of employment based KSGs and competencies. This alignment forms the basis for a national network of MATE colleges. It 
also helps improve the communication between students, educators, practicing technicians, and employers by providing common concepts and terminology for discussing how to improve marine advanced technology education.

\section{Methods}

Developing a competent marine technical workforce involves working with practicing marine technicians, employers, and government agencies to identify and define existing and future occupations within marine technology, and to estimate the demand for people to work in these occupations. (See steps 1 and 2 of Figure 1). The next step involves working closely with practicing technicians to identify the knowledge and skills needed to work in specific occupations (step 3 in Figure 1). The results of this step are knowledge and skill guidelines (KSGs) for specific occupations. KSGs are also referred to by some authors as occupational guidelines, occupational standards, or skill standards.

To develop KSGs, the MATE Center uses procedures similar to those outlined in the Skill Standards Guidebook I developed by the Washington State Board for Community and Technical Colleges and others (1). In brief, we select a marine occupation based on responses to employer surveys, other labor market information, and the advice of experts in the field. A highly structured workshop is then conducted with a group of eight to twelve invited technical professionals who work in, or are otherwise very involved in, the selected occupation. The type of workshop we use is often called a modified Developing A CUrriculuM (DACUM) workshop --or simply, a DACUM (2). The technical professionals work with a trained facilitator for one to two days to carefully define the job functions and tasks associated with the selected occupation. The information gathered during the workshop is used to develop draft guidelines that are then sent out for review and validation to dozens of technical professionals, representing large and small organizations from the public and private sector.

Identifying Competencies. The next step is to identify job requirements that are common to two or more occupations, and to link job requirements to educational subject areas (step 4 in Figure 1). The results of this step are the competencies.

The competencies are based on the MATE Center's KSGs and on a wide range of other resources. Existing occupational guidelines or skill standards developed by other organizations are especially useful supplements to the MATE Center's KSGs. Some of these organizations include other Advanced Technology Education (ATE) Centers, the U.S. Navy, and the International Hydrographic Organization. Guidelines and standards developed by organizations that are not specifically linked to marine technology can be very useful, especially in more general educational subject areas (e.g., computer systems, technical writing).

Position descriptions and job announcements are also very useful in identifying competencies. Descriptions for very different positions often list very similar qualifications, especially for the more fundamental qualifications. Existing teaching materials are also a good resource for developing competencies. Many course outlines, syllabi, and assessments contain elements of occupational competencies. This includes the material for both technical and academic courses taught at colleges and universities, technical schools (e.g., those run by the U.S. Navy), on the job courses, and courses taught by equipment manufacturers. A different set of resource materials was reviewed for each competency area.

Competency Levels. Within each educational subject area, there is a wide a range of competencies, from the most elementary to the most advanced. For employees whose specializations lie within a competency area, a higher level of competency would be expected in that area. But outside that specialization, the expectations would generally be lower. For example, someone whose specialty is electronics might be expected to have a high level of competency in electronics, an intermediate level of competency in computer systems, and a basic level of competency in safety and seamanship. To account for these different expectations, we have defined three levels of competency, described below.

A. Basic Competencies. Skills most potential employees would be expected to possess. Basic competencies address the most fundamental knowledge and skills. These fundamentals are typically learned in introductory courses or very early in a marine technician's career. An example of a basic competency from electronics is:

"Describe the differences between AC and DC voltage and current."

B. Intermediate Competencies. Skills many potential employees would be expected to possess. Intermediate competencies typically address the practical applications of basic competencies (skills) that employers are looking for. Intermediate competencies commonly involve applying more advanced knowledge and performing more advanced tasks. Intermediate competencies are generally gained by specializing as a student in that competency (e.g., electronics), or by 1-5 years of on-the-job experience. An example of an intermediate competency from electronics is:

"Conduct preventative maintenance on major electronic systems."

C. Specialized Competencies. Skills some potential employees would be expected to possess. Specialized competencies are typically acquired through advanced degrees, or by five or more years of work experience. An example of an advanced electronics competency is: "Conduct calibration of sensitive test and operational equipment. Administer calibration laboratory.”

Validation of the Competencies. Once a draft competency list is developed, it is reviewed by professionals working in that competency area. Their comments are then used to produce a draft for further review and circulation. At the end of this review process, the competencies are ready to be used in the development of instructional materials and services (see Figure 1). However, we continually revise the competencies as new information and the comments of users come in. 


\section{Conclusion}

These competencies are currently being tested and used by MATE staff, partners, practicing technicians, employers, educators, and students. They are being extensively used by the MATE staff, partners, and education consultants to develop new teaching materials and improve existing materials. These competency-based materials form the foundation for MATE educational courses and programs. The competencies are also being used as guidelines for developing continuing education programs for practicing technicians. Marine technology students and their faculty advisors are using the competencies to help students evaluate their qualifications for different occupations, and to prepare themselves for work in different fields. As the competencies are tested and used, feedback is being collected and used to improve the competencies. This feedback is also being used to improve the process of developing new competencies. Through these efforts, students and workers are discovering a broad range of career opportunities and can easily access detailed, current career information to make better and more informed choices about their education and future. To view all the competencies online please go to http://www.marinetech.org/marineworkforce/pdf/educational comps.pdf

\section{References:}

(1) The Boeing Corporation. 1996. Skill Standards Guidebook I. The Center for Career and Work-Related Education Washington State Board for Community and Technical Colleges.

(2) Norton, R.E. 1996. DACUM Handbook. Center on Education and Training for Employment, College of Education, The Ohio State University, 1900 Kenny Road, Columbus, Ohio 43210

\section{Acknowledgements:}

This project is supported in part by the National Science Foundation DUE/ATE-0302905. In addition many people contributed to the development of the competencies. We would like to especially thank the following people:

- Jim A.R. McFarlane, Co-Chairperson of the MATE Center's National Visiting Committee, and Director of Facilities Planning at the Monterey Bay Aquarium Research Institute

- Martha Diehl, Merchant Marine Captain (retired) and MATE Center consultant

- Ali Ameripod, Hydraulics Instructor, Hartnell College

- John Karnofel, Marine Technology Instructor, Hartnell College

- Sam Debow, NOAA/NOS/Office of Coastal Surveys, Hydrographic Surveys Division

- Marlene Martin, English Instructor, Monterey

Peninsula College

- David C. Monaghan, Marine

Superintendent/Instructor, Cape Fear Community College

- Marie Millis, Marine Laboratory Technician, Cape Fear Community College

- Mark V. Miller, Marine Science, Cape Fear Community College

- $\quad$ Stephen J. Beuth, Coordinator, Ship Operations/Captain/Instructor, Cape Fear Community College

- $\quad$ Raymond P. Brandi, Department Chair, Marine Technology, Cape Fear Community College

- Robert J. Parker, Marine Technician/Instructor, Cape Fear Community College

- Jason Rogers, Marine Technology Instructor, Cape Fear Community College

- Robert J. Philpott, Dean, Vocational/Technical Education, Cape Fear Community College 
Figures

\section{Strategy for Improving the Marine Technical Workforce}

Overarching Goal:

Recruit diverse students, prepare them for technical marine jobs, and improve the knowiedge and skills of practicing marine professionals.

\begin{tabular}{|c|c|}
\hline Outcomes & Products \\
\hline $\begin{array}{l}\text { 1. Needs } \\
\text { Identification }\end{array}$ & $\begin{array}{l}\text { List of critical workforce needs from industry } \\
\text { queries (e.g., online and w ritten surveys, advisory } \\
\text { committees, direct contact) }\end{array}$ \\
\hline $\begin{array}{l}\text { 2. Occupational } \\
\text { Definitions }\end{array}$ & $\begin{array}{l}\text { Industry and government recognized } \\
\text { occupational categories } \\
\text { (e.g., marine technician, aquarist) }\end{array}$ \\
\hline $\begin{array}{l}\text { 3. Occupational } \\
\text { Knowledge and Skill } \\
\text { Guidelines }\end{array}$ & \begin{tabular}{|} 
Industry-identified knowledge and skills for \\
specific occupations \\
(e.g., Rov technician, hydrographic survey technician, \\
marine technician)
\end{tabular} \\
\hline $\begin{array}{l}\text { 4. Skill cluster } \\
\text { Competencies }\end{array}$ & $\begin{array}{l}\text { Knowledge and skills grouped by subject area } \\
\text { (e.g., electronics, hydraulics, seamanship) }\end{array}$ \\
\hline $\begin{array}{l}\text { 5. Instructional } \\
\text { Materials and } \\
\text { Services }\end{array}$ & $\begin{array}{l}\text { Competency-based assessments, modules, } \\
\text { courses, faculty development workshops, and } \\
\text { internships }\end{array}$ \\
\hline $\begin{array}{l}\text { 6. Educational } \\
\text { Programs }\end{array}$ & $\begin{array}{l}\text { Degree and certificate programs based on } \\
\text { instructional materials }\end{array}$ \\
\hline $\begin{array}{l}\text { 7. Career } \\
\text { Management }\end{array}$ & $\begin{array}{c}\text { Job placement programs, professional } \\
\text { development courses }\end{array}$ \\
\hline
\end{tabular}

Figure 1. The MATE Center strategy for improving the marine technical workforce has seven major steps. 